\title{
Optimization of drying conditions of Cudrania tricuspidata using response surface methodology
}

\author{
Jong-Jin Park ${ }^{1}$, Dae-Hee Park ${ }^{1}$, Gayoung Jung ${ }^{2}$, Eunju Shin ${ }^{2}$, Seon-Gil Do ${ }^{2}$, \\ Wonyoung Lee $\mathrm{Le}^{1,3 *}$ \\ ${ }^{1}$ School of Food Science and Technology, Kyungpook National University, Daegu 41566, Korea \\ ${ }^{2}$ Wellness R\&D Center, Univera Inc., Seoul 04782, Korea \\ ${ }^{3}$ Food and Bio-industry Research Institute, Kyungpook National University, Daegu 41566, Korea
}

\section{반응표면분석법을 이용한 꾸지뽕의 블랜칭 처리 및 건조 조건 최적화}

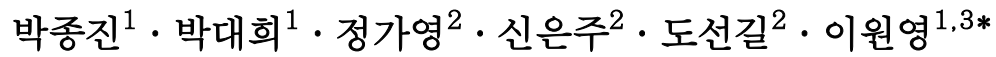 \\ ${ }^{1}$ 경북대학교 식품공학부, ${ }^{2}$ 유니베라 웰니스연구소, ${ }^{3}$ 식품생물산업연구소
}

\begin{abstract}
This study was conducted to obtain the optimal conditions of hot air drying for Cudrania tricuspidata by response surface methodology (RSM). The independent variables were blanching time $(60,120,240 \mathrm{sec})$, drying temperature $\left(40,60,80^{\circ} \mathrm{C}\right)$ and drying time $(12,24,36 \mathrm{~h})$. The dependant variables were total polyphenol content (TPC), total flavonoid content (TFC), DPPH radical scavenging activity (DPPH), and color difference $(\Delta E)$ ). Viable cell colony was counted according to changes of blanching time. It was confirmed that microorganisms gradually decreased with increasing blanching time. From RSM results, the predicted values of TPC, TFC, DPPH, and $\triangle \mathrm{E}$ were 8.62 $\mathrm{mg} \mathrm{GAE} / \mathrm{g}, 56.65 \mathrm{mg} \mathrm{RE} / \mathrm{g}, 40.26 \%$ and 11.69 , respectively. Experimental values within the optimal range (240 sec, blanching time; $60^{\circ} \mathrm{C}$, drying temperature; $24 \mathrm{~h}$, drying time) were $10.06 \mathrm{mg} \mathrm{GAE} / \mathrm{g}, 49 \mathrm{mg} \mathrm{RE} / \mathrm{g}, 44.99 \%$ and 10.53, respectively. The predicted values were similar to the experimental values. Comparing drying tendency according to changes of blanching time, moisture reduction was bigger in the blanched sample than that in control at $40^{\circ} \mathrm{C}$. However, the differences between blanched and control decreased with increase of drying temperature. Viable cell gradually decreased as increasing blanching time.
\end{abstract}

Key words : Cudrania tricuspidata, response surface methodology, optimization, drying condition, blanching

\section{서 론}

꾸지뽕나무(Cudrania tricuspidata)는 뽕나무과에 속하는 낙엽교목으로 전국 각지에서 자생하고 있는 작물이다(1) 예로부터 꾸지뽕의 열매와 수피는 강장, 중풍, 이뇨, 진해 등의 질병에 대한 약재로 사용되어 왔으며(2), 잎, 뿌리를 포함한 꾸지뽕의 여러 부위에서 혈당 상승 억제(3), 신경세

*Corresponding author. E-mail : wonyoung@knu.ac.kr Phone : 82-53-950-7763, Fax : 82-53-950-7762

Received 1 February 2017; Revised 14 February 2017; Accepted 16 February 2017.

Copyright (c) The Korean Society of Food Preservation. All rights reserved.
포 보호(4), 미백, 주름 개선(5) 등의 효과가 있는 것으로 보고되었다. 그 중 꾸지뽕의 열매는 익을수록 붉은색을 띄 는 둥근 모양으로 citric acid, potassium, alanine 등 다양한 유기산과 무기질, 유리아미노산을 함유하고 있는 것으로 알려져 있다(6,7). 꾸지뽕 열매는 간보호 효과(8), 알레르기 성 염증 억제(9), 항산화(10) 등이 있으며 열매를 발효한 후 나타나는 면역력 증강(11), elastase 및 tyrosinase 저해활 성(12)에 대해서도 보고된 바 있다. 이처럼 꾸지뽕 나무의 생리활성 효과에 대한 연구가 발표되면서 전라남북도를 중심으로 재배면적이 점점 늘어나고 있으며(13), 꾸지뽕 열매를 원료로 한 음료, 꾸지뽕 잎 차 등의 제품 개발도 활발하게 이루어지고 있다(14). 꾸지뽕 열매는 수확 후 냉장 보관을 하더라도 무르기 쉽고 미생물에 의한 오염으로 인해 
저장 기간이 짧은 문제점이 있어 대부분의 농가에서는 생과 를 냉동시키거나 건조를 하여 저장을 하고 있는 실정이다. 따라서 앞으로 꾸지뽕의 안정적인 수급과 제품화를 위해서 는 적절한 전처리기술과 건조조건의 확립이 필요할 것으로 사료되었다.

꾸지뽕 열매에 적용할 수 있는 다양한 처리 방법 중 블랜 칭과 열풍건조법에 주목하였는데, 블랜칭 처리는 시료를 짧은 시간 열수에 침지하는 공정으로 살균, 효소 불활성화 등 저장 중 품질저하 방지 효과가 있어 농산물의 수확 후 저장 전처리 기술로 적용되고 있고(15,16) 열풍 건조는 산업 적으로 가장 광범위하게 사용되고 있는 건조법으로 수분함 량을 감소시켜 미생물 오염을 억제하고 건조 제품만의 독특 한 특성을 나타내는 장점이 있다 $(17,18)$. 그러나 블랜칭 처 리는 열에 의해 영양분이 손실 될 수 있으며(19) 또한 열풍 건조도 장시간 처리 시 시료 내 영양성분 손실 및 색 변화를 유발할 수 있어 블랜칭과 건조조건 확립은 꾸지뽕의 보관 중 품질유지를 위해 중요하다 할 수 있다 $(20,21)$.

본 연구에서는 농가에서 갓 수확한 꾸지뽕에 블랜칭 처 리를 한 후 열풍 건조하였으며, 꾸지뽕 내의 유용 성분 손실 을 최소화하기 위해 반응표면 분석법을 사용하여 공정의 최적 조건을 제시하고자 하였다.

\section{재료 및 방법}

재 료

본 연구에서는 전라북도 순창군에서 수확한 꾸지뽕 (Cudrania tricuspidata) 열매를 사용하였으며, 구입한 시료 는 $5^{\circ} \mathrm{C}$ 에서 냉장보관 하였다.

\section{실험 설계}

꾸지뽕의 블랜칭 및 건조 조건 최적화를 위해 중심합성 계획법(central composite design)과 반응표면분석법(response surface methodology)을 적용하여 실험 설계를 하였다. 독립 변수 $\left(\mathrm{X}_{\mathrm{n}}\right)$ 는 블랜칭 처리 시간 $\left(\mathrm{X}_{1}\right)$, 건조 온도 $\left(\mathrm{X}_{2}\right)$, 건조 시간 $\left(\mathrm{X}_{3}\right)$ 으로 3 단계 $(-1,0,1)$ 로 부호화하였다(Table 1). 블랜칭 처리 시간, 건조 온도, 건조 시간 등의 독립변수들은 생균수 측정, 색차 등 예비실험을 통해 범위를 설정하였다. 그리고 독립변수에 영향을 받는 종속변수 $\left(\mathrm{Y}_{\mathrm{n}}\right)$ 는 total polyphenol content $\left(\mathrm{Y}_{1}\right)$, total flavonoid content $\left(\mathrm{Y}_{2}\right)$, DPPH radical scavenging activity $\left(\mathrm{Y}_{3}\right)$, 색차 $\left(\mathrm{Y}_{4}\right)$ 로 설정하였고 측정 결과 값은 SAS software(SAS, Version 9.2, SAS Institute Inc., Cary, NC, USA)를 사용하여 분석하였다. SAS software에서 산출된 예측 모델식은 Mathematica(Mathematica, Wolfram, Champaign, IL, USA)에 대입되어 4D 그래프로 나타내었다. 그리고 각 4D 그래프를 superimposing 함으로써 꾸지뽕의 블랜칭 및 건조 최적 조건을 설정하였다.
Table 1. The central composite design for optimization of drying condition of Cudrania tricuspidata

\begin{tabular}{ccccc}
\hline $\mathrm{X}_{\mathrm{n}}$ & Response variables & -1 & 0 & 1 \\
\hline $\mathrm{X}_{1}$ & Blanching time (sec) & 0 & 120 & 240 \\
$\mathrm{X}_{2}$ & Drying temperature & 40 & 60 & 80 \\
$\mathrm{X}_{3}$ & Drying time (h) & 12 & 24 & 36 \\
\hline
\end{tabular}

\section{블랜칭 및 열풍 건조방법}

꾸지뽕은 $90^{\circ} \mathrm{C}$ 의 열수에서 $60-240$ 초 간 블랜칭 처리 후 $20^{\circ} \mathrm{C}$ 수도수에 3 분간 침지하여 냉각하였다. 시료의 열풍 건조는 열풍건조기(OTEC-004-m, Ilwon freezer, Namyangju, Korea)를 이용하여 $40,60,80^{\circ}$ C에서 $12-36$ 시간 동안 건조를 진행하였다.

\section{수분함량 측정}

건조 시간에 따른 꾸지뽕의 수분함량 $\left(\mathrm{M}_{\mathrm{c}}\right)$ 은 아래 식을 이용하여 계산하였다(22).

$$
M_{c}=\frac{M_{t}}{M} \times 100
$$

$\mathrm{M}_{\mathrm{c}}$ : sample의 총량 $(\mathrm{g})$

$\mathrm{W}_{\mathrm{t}}$ : 건조 시간 $\mathrm{t}$ 일 때 시료의 수분함량 $(\mathrm{g})$

\section{생균수 측정}

꾸지뽕의 생균수를 측정하기 위하여 생과 $15 \mathrm{~g}$ 과 멸균된 $0.1 \%$ 펩톤수 $135 \mathrm{~mL}$ 를 stomacher(SH-001, SHIMSKYU, Tokyo, Japan)를 이용하여 균질화하였다. 균질한 현탁액은 연속 희석한 후 petrifilm(3M petrifilm, 3M Co., Minnesota,

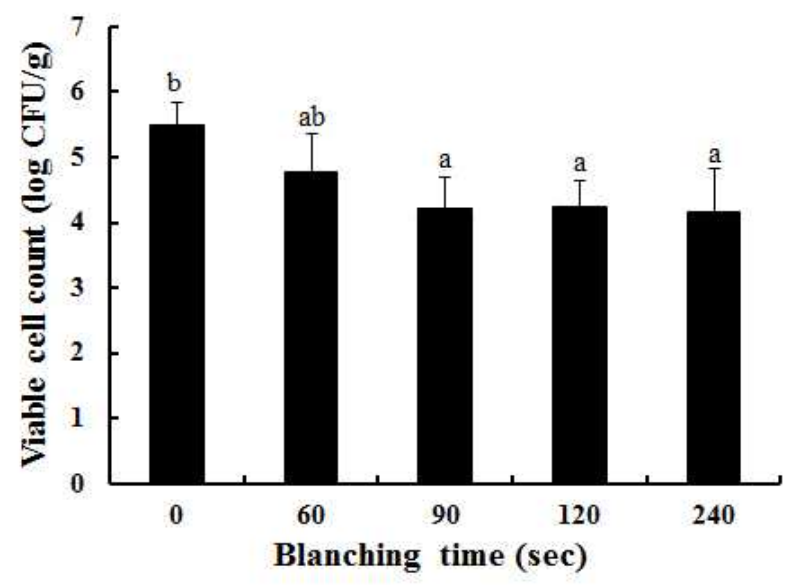

Fig. 1. Measurement of viable cell count of Cudrania tricuspidata according to blanching times.

Mean with the difference letter $(\mathrm{a}-\mathrm{b})$ are by DMRT $(\mathrm{p}<0.05)$. 
USA) 에 접종 후 $37^{\circ} \mathrm{C}$ 에서 48 시간동안 배양하였다. 배양한 petrifilm의 집락수를 계수하여 $\mathrm{g}$ 당 $\log$ colony forming unit(log CFU/g)으로 나타내었다(Fig. 1).

\section{추출액 제조}

꾸지뽕 시료는 중심합성계획법에 의해 설계된 조건에 따라 블랜칭 처리 및 열풍 건조되었으며, 잔여 수분에 따른 분석오차를 줄이기 위해 모든 시료를 동결 건조하였다. 동 결 건조를 통해 완전히 건조된 시료는 분쇄기(RT-02, Mill powder tech solutions, Tainan city, Taiwan)를 사용하여 분말 화 되었다. 분쇄된 분말은 sieve를 사용하여 $60 \mathrm{mesh}$ 크기로 선별하였다. 선별된 분말 $1 \mathrm{~g}$ 과 $95 \%$ 에탄올 $50 \mathrm{~mL}$ 를 추출용 기에 넣은 후 마이크로웨이브 추출장치(Soxwave 100, Prolab, Fontenay, France)를 사용하여 $240 \mathrm{~W}$ 에서 10 분 간 추출하였다. 추출액은 여과지(Whatman No.1, Whatman Co., Maidstone, England)를 사용하여 감압 여과되었으며, 여과액은 mass flask를 사용하여 $100 \mathrm{~mL}$ 로 정량 후 분석용 시료로 사용되었다.

총 폴리페놀 함량(Total polyphenol content, TPC) 꾸지뽕 추출물의 총 폴리페놀 함량(TPC)은 Folin-Denis 법(23)을 변형시켜 측정하였다. 먼저 추출액 $100 \mu \mathrm{L}$ 에 Folin-Ciocalteu reagent $50 \mu \mathrm{L}$ 를 가한 뒤 $2 \% \mathrm{Na}_{2} \mathrm{CO}_{3} 300$ $\mu \mathrm{L}$ 를 넣고 실온에 15 분 간 반응시켰다. 반응이 끝나면 1 $\mathrm{mL}$ 의 증류수를 넣은 후 UV-spectrophotometer(Shimazdu Co. UV-2550, Tokyo, Japan)를 이용하여 $725 \mathrm{~nm}$ 에서 흡광 도를 측정하였다. 검량곡선은 gallic acid(Sigma-Aldrich, St. Louis, MO, USA)를 표준물질로 작성하였다. 측정 결과는 $\mathrm{mg}$ of gallic acid equivalent per $\mathrm{g}(\mathrm{mg} \mathrm{GAE} / \mathrm{g})$ 로 나타내었다.

총 플라보노이드 함량(Total flavonoid content, TFC) 꾸지뽕 내의 총 플라보노이드 함량(TFC)을 측정하기 위 해 aluminum colorimetric assay(24)를 사용하였다. 먼저 추 출액 $70 \mu \mathrm{L}$ 과 증류수 $430 \mu \mathrm{L}$ 를 넣은 다음 $5 \% \mathrm{NaNO}_{2} 50$ $\mu \mathrm{L}$ 를 첨가하였다. 그리고 $10 \% \mathrm{AL}\left(\mathrm{NO}_{3}\right)_{3} \cdot 9 \mathrm{H}_{2} \mathrm{O}$ 를 가한 뒤 상온에서 6분간 반응시켰다. 반응 후 $1 \mathrm{~N} \mathrm{NaOH} 500 \mu \mathrm{L}$ 를 첨가한 다음 UV-spectrophotometer를 이용하여 $510 \mathrm{~nm}$ 에서 흡광도를 측정하였다. 표준 물질은 Rutin(Sigma-Aldrich Co.)을 사용하였으며 측정 결과는 $\mathrm{mg}$ of rutin equivalent per $\mathrm{g}(\mathrm{mg} \mathrm{RE} / \mathrm{g})$ 으로 나타내었다.

\section{DPPH 라디컬 소거능(DPPH radical scavenging} activity, DPPH)

꾸지뽕의 DPPH radical scavenging activity 측정은 Blois 의 방법(25)을 변형하여 사용하였다. 먼저 DPPH 시약은 0.0039 g 2,2-diphenyl-1-picryhydrazyl(Sigma-Aldrich Co.)에 $100 \mathrm{~mL}$ 에탄올을 첨가 후 magnetic stirrer(PC-420D,
Corning Co., Corning, NY, USA)로 2시간 동안 교반하여 제조하였다. 제조된 $\mathrm{DPPH}$ 시약은 $100 \mu \mathrm{L}$ 추출액과 섞은 후 30 분 간 암실에서 반응시켰다. 반응이 완료된 시약은 UV-spectrophotometer를 사용하여 $517 \mathrm{~nm}$ 에서 흡광도를 측 정하였으며 결과값을 아래 식에 대입하여 $\mathrm{DPPH}$ 소거능으 로 나타내었다.

$\operatorname{DPPH}(\%)=[1$-sample absorbance/blank absorbance $) \times 100]$

\section{색도 측정}

색도 측정은 꾸지뽕 표면을 색차계(CR-300, Minolta Co., Osaka, Japan)를 이용하여 측정하였다. 측정 전 표준 백색판 $(\mathrm{L}=97.78, \mathrm{a}=0.39, \mathrm{~b}=2.05)$ 으로 기기를 보정하였다. 꾸지뽕 시료 하나당 무작위로 3 부분을 측정하여 Hunter's color value인 명도(L, lightness), 적색도(a, redness), 황색도(b, yellowness) value를 구한 후 결과값을 아래 식에 대입하여 $\triangle \mathrm{E}$ value로 나타내었다.

$$
\Delta E=\sqrt{\triangle L^{2}+\triangle a^{2}+\Delta b^{2}}
$$

\section{통계처리 및 분석}

실험구 간의 유의성을 확인하기 위해 IBM SPSS software(version 22, SPSS Inc., Chicago, IL, USA)를 사용하 여 Duncan's multiple range test를 하였으며, 유의성 분석은 $\mathrm{p}<0.05$ 수준에서 진행되었다.

\section{결과 및 고찰}

\section{블랜칭 처리에 따른 미생물 감소 효과}

블랜칭 처리 후 나타나는 꾸지뽕의 생균수 변화는 Fig. 1 과 같다. 수도수에 3 분 간 침지시킨 control의 생균수는 $5.49 \log \mathrm{CFU} / \mathrm{g}$ 이었고 $90^{\circ} \mathrm{C}$ 의 열수에 60 초 간 블랜칭 처리 했을 때는 $4.78 \log \mathrm{CFU} / \mathrm{g}$ 이었다. 그리고 $90,120,240$ 초 간 블랜칭 처리 시 생균수는 각각 4.22, 4.24, $4.16 \log \mathrm{CFU} / \mathrm{g}$ 으로 control과 비교했을 때 유의적인 차이를 나타내었다 $(\mathrm{p}<0.05)$. 이와 유사하게 $\mathrm{Kim}$ 등(26)이 연구한 참취도 블랜 칭 처리 시간이 증가함에 따라 생균수가 감소하는 결과를 나타내었다. 과채류는 수확 후 저장 중 조직손상, 미생물에 의한 부패현상, 신선도 변화 등의 품질변화가 일어날 수 있기 때문에 블랜칭과 같은 열처리는 효과적인 미생물 저감 화 처리방법이 될 수 있다(26,27).

\section{블랜칭 처리와 건조 온도가 건조 추세에 미치는 영향}

블랜칭 및 건조 조건에 따른 꾸지뽕의 건조 추세는 Fig. 2 에 나타내었다. 꾸지뽕을 $40^{\circ} \mathrm{C}$ 에서 열 풍 건조하였을 때 수분함량이 $10 \%$ 이하가 되기까지 무처리구는 약 146 시간 
(A)

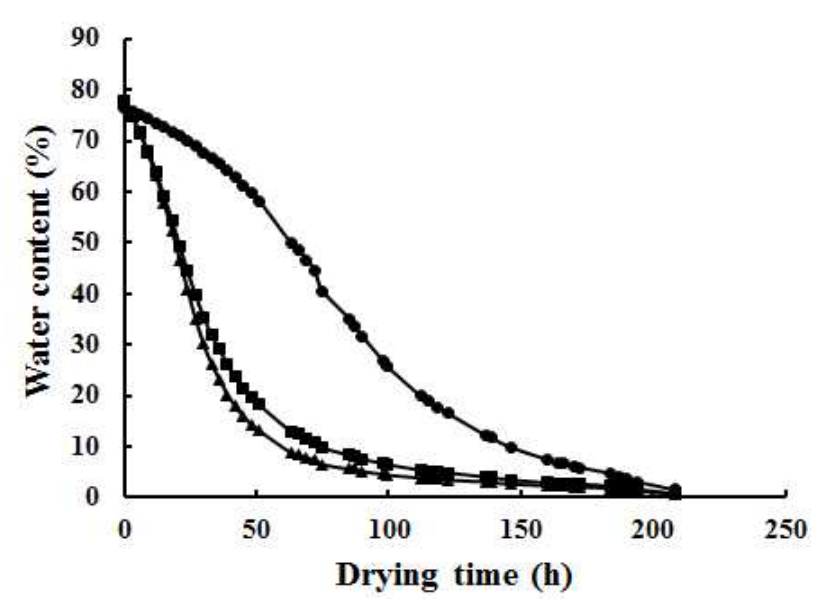

(C)

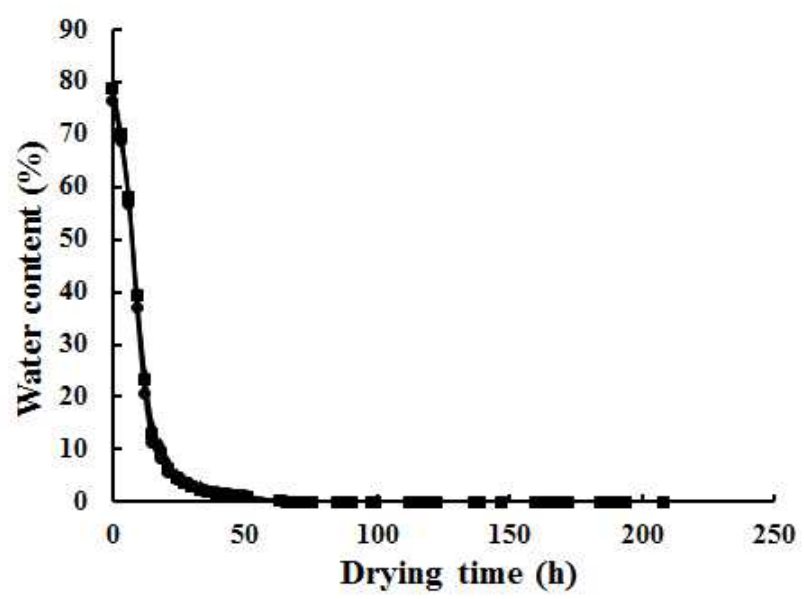

(B)

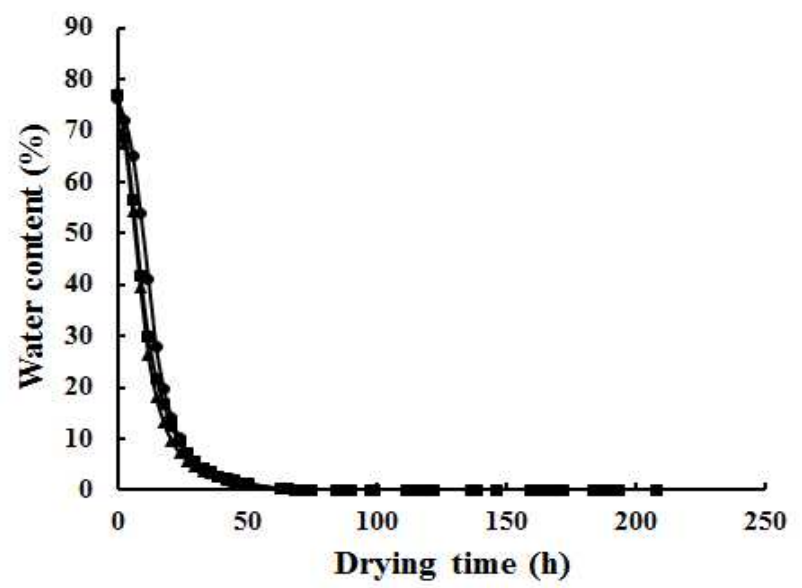

Fig. 2. Experimental drying tendency of Cudrania tricuspidata depending on blanching times and drying temperatures.

A, drying at $40^{\circ} \mathrm{C}$; B, drying at $60^{\circ} \mathrm{C}$; C, drying at $80^{\circ} \mathrm{C}$.

, non-treatment sample; $\mathbf{D}, 120 \mathrm{sec}$ blanched sample; $\boldsymbol{\Delta}, 240 \mathrm{sec}$ blanched sample.

이 걸린 반면, 120 초 간 블랜칭 처리한 군은 약 75 시간, 240 초 처리군은 63 시간이 소요되었다. 실험 결과로 보았을 때, 블랜칭 처리를 하게 되면 꾸지뽕의 수분 감소 속도가 증가한다는 것을 확인할 수 있었다. 이와 유사하게 Chung 등(28)이 실험한 고추에서의 blanching 처리는 고추의 건조 율 향상 및 색의 보존에 효과적이었다고 보고하였으며 또한 Pirone 등(29)은 미성숙 sweet cherry를 블랜칭 후 건조 시 수분 이동량이 증가함과 동시에 특정 수분함량에 도달하는 데 필요한 시간이 단축되었다고 보고하였다. 이는 블랜칭 처리로 인한 cellular membrane 파괴 및 조직의 물리적 변화 와 연관이 있다고 서술하였다(30). 그리고 $60^{\circ} \mathrm{C}$ 의 건조온도 에서는 무처리구와 120 초 처리군은 약 24 시간, 240 초 처리 군에서는 약 21 시간 건조했을 때 $10 \%$ 이하의 수분함량을 나타냈으며 건조온도 $80^{\circ} \mathrm{C}$ 에서는 처리구간의 차이가 거의 나타나지 않았다(Table 2). 이로 미루어볼 때 블랜칭 처리는 꾸지뽕의 수분 함량 감소가 빠르게 이루어지도록 하지만 건조 온도가 높아질수록 그 효과는 줄어드는 것으로 나타났
다. 비슷한 사례로 Borges 등(31)의 연구에는 바나나를 $40^{\circ} \mathrm{C}$ 에서 건조하였을 때 블랜칭 처리구와 무처리구 간의 차이가 명확했지만 $70^{\circ} \mathrm{C}$ 에서는 차이가 나타나지 않았는데, 이와

Table 2. Moisture content according to change of blanching time under $36 \mathrm{~h}$ drying time

\begin{tabular}{ccc}
\hline Temperature $\left({ }^{\circ} \mathrm{C}\right)$ & Blanching time $(\mathrm{sec})$ & Moisture content $(\%)$ \\
\hline \multirow{3}{*}{40} & 0 & 46.05 \\
& 120 & 6 \\
& 240 & 4.66 \\
\hline \multirow{2}{*}{60} & 0 & 0.74 \\
& 120 & 0.71 \\
& 240 & 0.68 \\
\hline \multirow{3}{*}{80} & 0 & 0.47 \\
& 120 & 0.43 \\
& 240 & 0.48 \\
\hline
\end{tabular}


같은 건조 추세의 차이는 $65^{\circ} \mathrm{C}$ 이상에서 발생하는 바나나 전분의 gelatinization과 연관이 있다고 보고하였다(32). 따 라서 본 연구에서 $80^{\circ} \mathrm{C}$ 에서 건조 시 블랜칭 처리군과 무처 리군 간 건조 추세가 차이가 미미한 것도 꾸지뽕의 구조적 변화와 연관이 있다고 사료된다.
블랜칭과 건조 조건이 총 폴리페놀 함량(TPC)에 미치는 영향

페놀 화합물은 다양한 식물에 존재하는 2 차 대사산물로 써 독특한 맛과 향 그리고 건강에 도움이 되는 성분이기 때문에 페놀성 화합물의 함량 증가는 품질 향상에 기여할

Table 3. Central composite design matrix for total polyphenol content (TPC), total flavonoid content (TFC), DPPH radical scavenging activity $(\mathrm{DPPH})$ and color difference $(\Delta \mathrm{E})$ of Cudrania tricuspidata under blanching and drying conditions

\begin{tabular}{|c|c|c|c|c|c|c|c|c|}
\hline Exp. & No. & $\begin{array}{l}\text { Blanching time } \\
(\mathrm{sec})\end{array}$ & Drying temp $\left({ }^{\circ} \mathrm{C}\right)$ & Drying time (h) & TPC (mg GAE/g) & TFC (mg RE/g) & DPPH $(\%)$ & $\Delta \mathrm{E}$ \\
\hline 1 & & $120(0)$ & $80(1)$ & $36(1)$ & $10.12 \pm 0.62$ & $33.74 \pm 2.77$ & $48.84 \pm 1.20$ & 24.21 \\
\hline 2 & & $0(-1)$ & $40(-1)$ & $24(0)$ & $10.76 \pm 0.30$ & $64.01 \pm 1.79$ & $41.34 \pm 1.64$ & 4.93 \\
\hline 3 & & $120(0)$ & $60(0)$ & $24(0)$ & $9.33 \pm 0.19$ & $56.31 \pm 3.19$ & $39.01 \pm 0.44$ & 13.76 \\
\hline 4 & & $120(0)$ & $40(-1)$ & $36(1)$ & $10.59 \pm 0.31$ & $71.96 \pm 1.13$ & $37.59 \pm 3.95$ & 5.09 \\
\hline 5 & & $0(-1)$ & $80(1)$ & $24(0)$ & $9.55 \pm 0.10$ & $41.39 \pm 1.48$ & $44.65 \pm 1.64$ & 22.77 \\
\hline 6 & & $240(1)$ & $40(-1)$ & $24(0)$ & $7.93 \pm 0.29$ & $52.24 \pm 0.66$ & $42.21 \pm 0.70$ & 2.28 \\
\hline 7 & & $240(1)$ & $60(0)$ & $12(-1)$ & $8.20 \pm 0.28$ & $49.05 \pm 4.83$ & $36.93 \pm 1.71$ & 2.72 \\
\hline 8 & & $0(-1)$ & $60(0)$ & $12(-1)$ & $9.35 \pm 0.36$ & $51.52 \pm 2.91$ & $32.39 \pm 0.82$ & 13.51 \\
\hline 9 & & $240(1)$ & $80(1)$ & $24(0)$ & $9.23 \pm 0.14$ & $40.81 \pm 1.35$ & $51.27 \pm 0.74$ & 17.42 \\
\hline 10 & & $0(-1)$ & $60(0)$ & $36(1)$ & $9.58 \pm 0.42$ & $48.9 \pm 2.57$ & $38.17 \pm 0.95$ & 19.98 \\
\hline 11 & & $120(0)$ & $60(0)$ & $24(0)$ & $9.60 \pm 0.00$ & $64.5 \pm 4.65$ & $35.48 \pm 0.58$ & 14.63 \\
\hline 12 & & $120(0)$ & $40(-1)$ & $12(-1)$ & $8.62 \pm 0.29$ & $35.48 \pm 2.44$ & $34.75 \pm 0.98$ & 3.43 \\
\hline 13 & & $120(0)$ & $80(1)$ & $12(-1)$ & $9.06 \pm 0.30$ & $47.35 \pm 0.66$ & $36.14 \pm 0.76$ & 13.07 \\
\hline 14 & & $240(1)$ & $60(0)$ & $36(1)$ & $9.32 \pm 0.05$ & $53.74 \pm 4.52$ & $35.01 \pm 2.68$ & 17.92 \\
\hline 15 & & $120(0)$ & $60(0)$ & $24(0)$ & $9.57 \pm 0.47$ & $66.68 \pm 2.53$ & $37.12 \pm 1.36$ & 15.57 \\
\hline
\end{tabular}

Table 4. The second polynomial equations for quality prediction of Cudrania tricuspidata calculated by SAS program

\begin{tabular}{|c|c|c|c|}
\hline Response $^{1)}$ & The second polynomial equations & $\mathrm{R}^{2}$ & Significance \\
\hline $\mathrm{TPC}$ & $\begin{array}{c}\mathrm{Y}=10.877500-0.019000 \mathrm{X}_{1}-0.061125 \mathrm{X}_{2}+0.110208 \mathrm{X}_{3}-0.000021441 \mathrm{X}_{1}^{2} \\
+0.000261 \mathrm{X}_{2} \mathrm{X}_{1}+0.000441 \mathrm{X}_{2}^{2}+0.000155 \mathrm{X}_{3} \mathrm{X}_{1}-0.000948 \mathrm{X}_{3} \mathrm{X}_{2}-0.000547 \mathrm{X}_{3}^{2}\end{array}$ & 0.9161 & 0.0395 \\
\hline TFC & $\begin{array}{c}Y=-90.351250-0.034101 \mathrm{X}_{1}+3.216875 \mathrm{X}_{2}+5.601424 \mathrm{X}_{3}-0.000320 \mathrm{X}_{1}^{2} \\
+0.001166 \mathrm{X}_{2} \mathrm{X}_{1}-0.020683 \mathrm{X}_{2}^{2}+0.001274 \mathrm{X}_{3} \mathrm{X}_{1}-0.052177 \mathrm{X}_{3} \mathrm{X}_{2}-0.049242 \mathrm{X}_{3}^{2}\end{array}$ & 0.9186 & 0.0286 \\
\hline DPPH & $\begin{array}{c}Y=76.027500-0.027608 \mathrm{X}_{1}-1.867438 \mathrm{X}_{2}+0.932222 \mathrm{X}_{3}+0.000137 \mathrm{X}_{1}^{2} \\
+0.000599 \mathrm{X}_{2} \mathrm{X}_{1}+0.014211 \mathrm{X}_{2}^{2}-0.001337 \mathrm{X}_{3} \mathrm{X}_{1}+0.010271 \mathrm{X}_{3} \mathrm{X}_{2}-0.024708 \mathrm{X}_{3}^{2}\end{array}$ & 0.9303 & 0.0200 \\
\hline$\Delta \mathrm{E}$ & $\begin{array}{c}Y=-23.338750-0.035212 X_{1}+0.915500 X_{2}-0.161840 X_{3}-0.000025029 X_{1}^{2} \\
-0.000281 X_{2} X_{1}-0.006107 X_{2}^{2}+0.001516 X_{3} X_{1}+0.009875 X_{3} X_{2}-0.005281 X_{3}^{2}\end{array}$ & 0.9782 & 0.0012 \\
\hline
\end{tabular}

${ }^{11)} \mathrm{TPC}$, total polyphenol content; TFC, total flavonoid content; DPPH, DPPH radical scavenging activity; $\Delta \mathrm{E}$, Color difference.

Table 5. Analysis of variance (ANOVA) results for TPC, TFC, DPPH and $\triangle \mathrm{E}$ of Cudrania tricuspidata under blanching and hot air drying

\begin{tabular}{ccccccc}
\hline & Model & $\mathrm{R}^{2}$ & Blanching time $(\mathrm{sec})$ & Drying temp $\left({ }^{\circ} \mathrm{C}\right)$ & Drying time $(\mathrm{h})$ & Stationary point \\
\hline $\mathrm{TPC}^{1)}$ & $5.36^{\left.* *^{2}\right)}$ & 0.9061 & $7.60^{* *}$ & 3.05 & $4.55^{\star}$ & saddle point \\
$\mathrm{TFC}$ & $7.63^{* *}$ & 0.9186 & 1.15 & $11.54^{* *}$ & $7.63^{* *}$ & maximum \\
$\mathrm{DPPH}$ & $7.42^{* *}$ & 0.9303 & 2.12 & $10.28^{* *}$ & $5.94^{* *}$ & saddle point \\
$\Delta \mathrm{E}$ & $24.91^{* *}$ & 0.9782 & $5.69^{* *}$ & $39.27^{* * *}$ & $48.04^{* *}$ & saddle point \\
\hline
\end{tabular}

\footnotetext{
${ }^{1)} \mathrm{TPC}$, total polyphenol content; TFC, total flavonoid content; DPPH, DPPH radical scavenging activity; $\triangle \mathrm{E}$, Color difference.
}

${ }^{2)} * * * \mathrm{p}<0.001, * * 0.001<\mathrm{p}<0.05, * 0.05<\mathrm{p}<0.1$. 
수 있다고 알려져 있다(33,34). 블랜칭 및 건조 조건에 따른 꾸지뽕의 TPC는 Table 3에 나타내었으며, 적합 모델식은 Table 4에 나타냈다. ANOVA 분석 결과 모델은 5\% 수준에 서 유의성을 나타내었으며, $\mathrm{R}^{2}$ 값은 0.9161 으로 확인되었다. 그리고 처리조건 중 블랜칭 처리 시간이 TPC 변화에 5\% 수준에서 유의적인 영향을 보였으나 건조 온도, 시간은 $\mathrm{TPC}$ 변화에 크게 많은 영향을 미치지 않았다(Table 5). 그리 고 Fig. 3에서 조건에 따른 TPC의 추세를 보았을 때, 블랜칭 처리 시간이 증가할수록 총 폴리페놀 함량은 서서히 감소하 는 것을 확인할 수 있었다. 이처럼 블랜칭 처리 시간 증가에 따른 TPC의 감소는 블랜칭에 의한 시료 조직의 연화로 인해 열수로 영양성분이 용출되었기 때문에 발생된 것으로 사료된다(35).

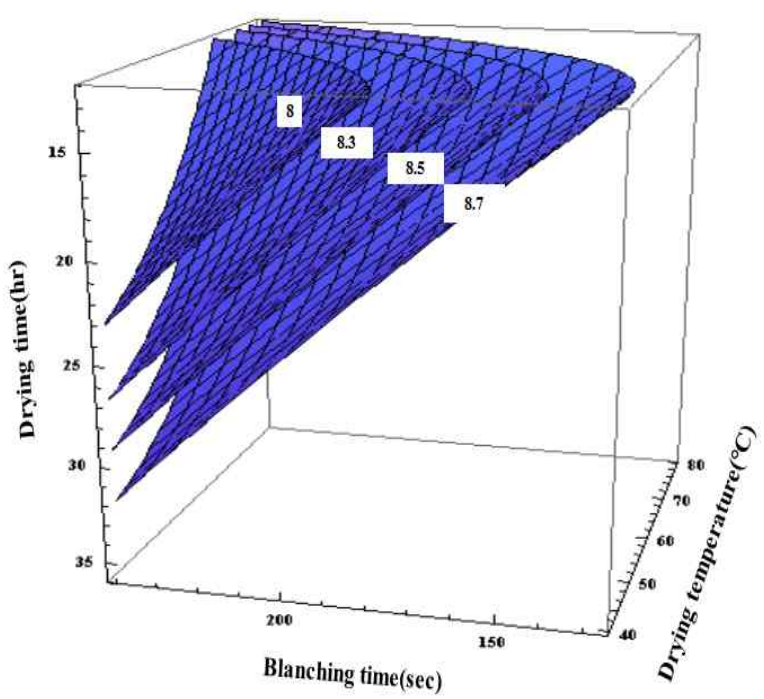

Fig. 3. Response surface for total polyphenol content of Cudrania tricuspidata at constant values (TPC: $8,8.3,8.5,8.7 \mathrm{mg} \mathrm{GAE} / \mathrm{g}$ ) as a function of blanching time, drying temperatures and drying times.

\section{블랜칭과 건조 조건이 총 플라보노이드 함량(TFC)에 미} 치는 영향

블랜칭 및 건조 조건에 따른 꾸지뽕의 $\mathrm{TFC}$ 는 Table 3 와 같으며, 적합 모델식은 Table 4에 나타냈다. ANOVA 분석 결과는 Table 5 에 나타내었다. 모델은 5\% 수준에서 유의성 을 보였으며 $\mathrm{R}^{2}$ 값은 0.9186 이었다. $\mathrm{TFC}$ 에 영향을 미치는 조건은 건조 온도와 시간으로 두 조건 모두 5\% 수준에서 유의적으로 영향력을 나타내었다. 반면 블랜칭 처리 시간 은 TFC에 큰 영향을 나타내지 않는 것으로 확인되었다. Dewanto 등(36)은 과실에 대한 열처리는 TFC를 유의적으 로 변화시키지 않는다고 보고하였는데, 본 연구에서 꾸지 뽕에 블랜칭으로 열처리를 했을 때 $\mathrm{TFC}$ 가 큰 변화가 없는 것도 이와 관련이 있는 것으로 생각된다. Fig. 4에서 처리조 건에 따른 꾸지뽕의 TFC 변화 추세를 확인해보았을 때,
건조 온도가 증가할수록 $\mathrm{TFC}$ 는 감소하였다. 이는 Jin 등 (37)이 다래과실을 열풍 건조하였을 때 나타난 결과와 비슷 한 경향을 나타내었다.

\section{블랜칭과 건조 조건이 $\mathrm{DPPH}$ 라디칼소거능( $\mathrm{DPPH})$ 에 미치는 영향}

블랜칭 및 건조 조건에 따른 꾸지뽕의 DPPH는 Table 3 에 나타내었으며, 적합 모델식은 Table 4에 나타냈다.

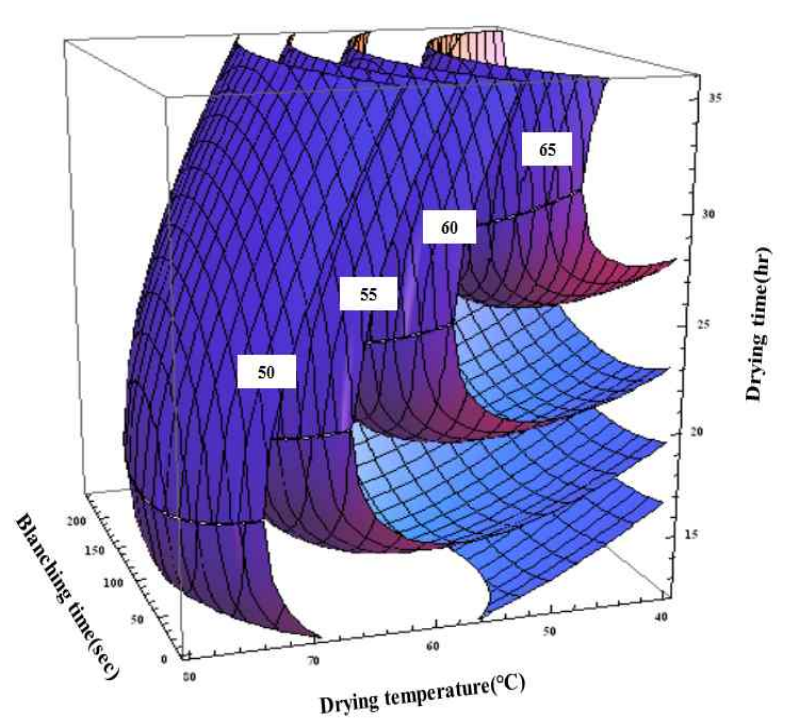

Fig. 4. Response surface for total flavonoid content of Cudrania tricuspidata at constant values (TFC: $50,55,60,65 \mathrm{mg} \mathrm{RE} / \mathrm{g}$ ) as a function of blanching times, drying temperatures and drying times.

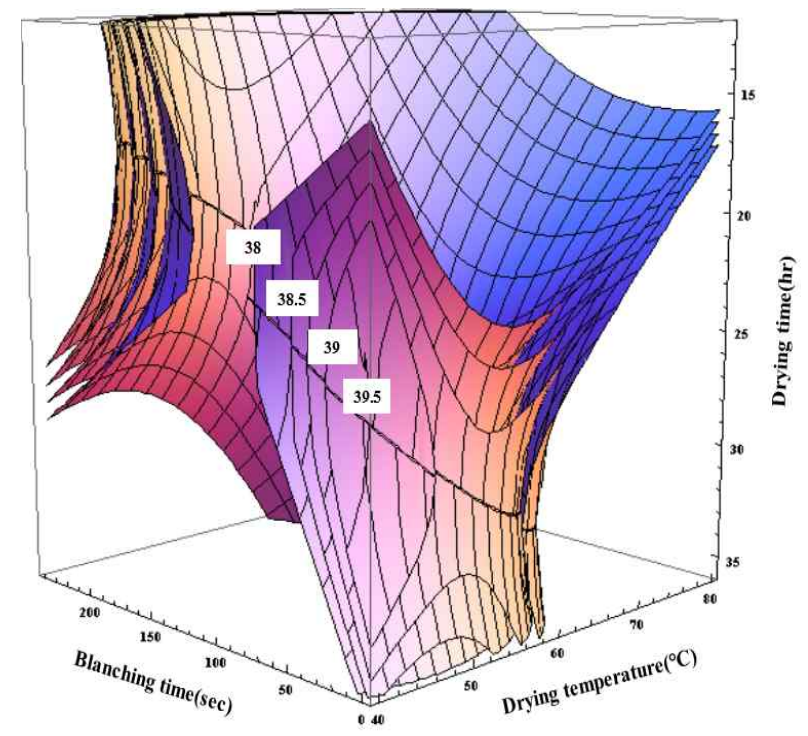

Fig. 5. Response surface for DPPH radical scavenging activity of Cudrania tricuspidata at constant values (DPPH: 38, 38.5, 39, $39.5 \%$ ) as a function of blanching times, drying temperatures and drying times. 
ANOVA 분석 결과 모델은 $5 \%$ 수준에서 유의성을 보였으 며 $\mathrm{R}^{2}$ 값은 0.9303 으로 나타났다. 처리 조건 중 $\mathrm{DPPH}$ 에 영향 을 미치는 인자는 건조 온도와 시간으로 $5 \%$ 유의수준에서 유의성이 있으며, 블랜칭 처리 시간은 크게 영향을 미치지 않는 것으로 확인되었다. 항산화 효과는 페놀성 화합물, 플라보노이드, 카로티노이드 등 식물의 2 차 대사산물에 의 해 발생한다고 알려져 있다(38). 본 연구에서 $\mathrm{DPPH}$ 가 건조 조건에 따라 뚜렷한 변화 추세를 보이지 않았는데(Fig. 5), 이는 건조 조건에 따라 꾸지뽕 내의 생리활성 물질의 증감 이 다르게 일어난 것이 원인이라고 추측된다.

\section{블랜칭과 건조 조건이 색도에 미치는 영향}

블랜칭 및 건조 조건에 따른 꾸지뽕의 색차는 Table 3에 나타내었으며 적합 모델식은 Table 4에 나타냈다. ANOVA 분석 결과 모델은 $5 \%$ 수준에서 유의성을 보였으며 $\mathrm{R}^{2}$ 값은 0.9782 으로 나타났다. 처리 조건 중 블랜칭 처리 시간과 건조 시간은 $5 \%$ 유의수준에서 색차에 영향을 미쳤으며, 건조 온도는 $0.1 \%$ 유의수준에서 영향력을 나타내었다 (Table 5). Fig. 6의 그래프를 분석해보았을 때 꾸지뽕의 건조 온도가 증가할수록 색차는 점점 증가하였으며, 동일 온도 및 시간에서 꾸지뽕을 건조했을 때 블랜칭 처리 시간 을 늘릴수록 색차는 점점 감소하는 추세를 보였다. 대부분 의 과채류에는 효소적 갈변을 유발하는 polyphenol oxidase $(\mathrm{PPO})$ 가 존재하며, 여러 연구 결과에서 열처리 공정 을 통해 과채류의 $\mathrm{PPO}$ 를 불활성화하여 갈변을 억제한 바 있다 $(39,40)$. 따라서 본 연구에서 블랜칭 처리가 건조 시 색차를 감소시킨 결과는 블랜칭 처리가 꾸지뽕 내의 polyphenol oxidase를 불활성화시켜 효소적 갈변을 억제한

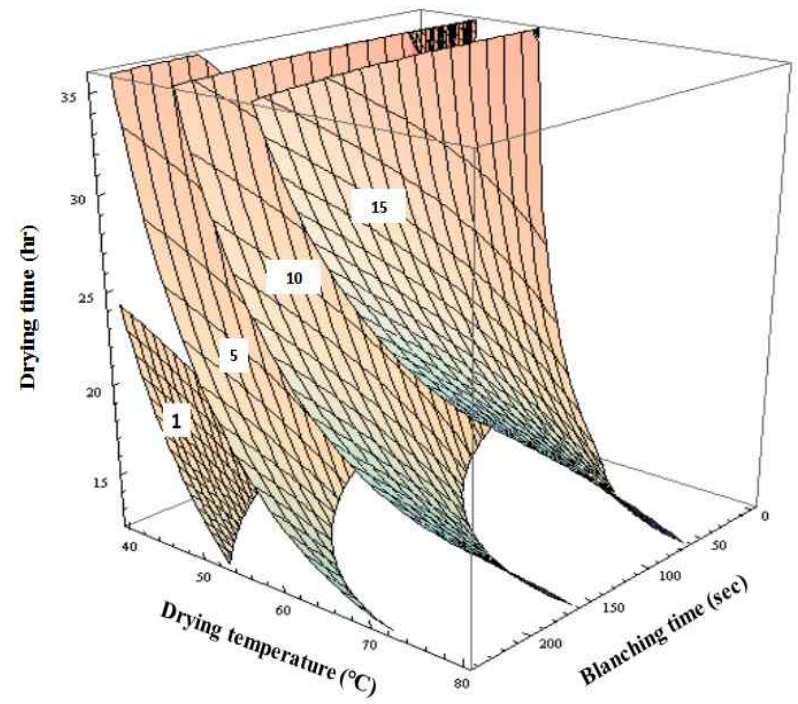

Fig. 6. Response surface for color difference of Cudrania tricuspidata at constant values $(\Delta \mathrm{E}: 1,5,10,15)$ as a function of blanching times, drying temperatures and drying times.
것으로 사료된다.

\section{최적 조건 예측}

공정의 최적화는 식품 산업에 있어서 중요 공정의 변수 모니터링과 고품질의 제품을 생산하는데 있어 중요한 부분 이며(21), 특히 건조 공정에서는 영양분 손실을 최소화할 수 있는 mathematical model을 산출할 수 있다는 장점이 있다(41). 꾸지뽕의 블랜칭 및 건조 공정의 최적 조건을 설정하기 위해서 각 조건별 추출물의 총 폴리페놀 함량, 총 플라보노이드 함량, 항산화 활성 그리고 색차 등의 contour maps를 superimposing하여 최적 범위를 예측하였다 (Fig. 7). 블랜칭 처리 시간 $200-240$ 초, 건조 온도 $50-60^{\circ} \mathrm{C}$, 건조 시간 24-30 시간 범위가 최적 조건으로 예측이 되었으

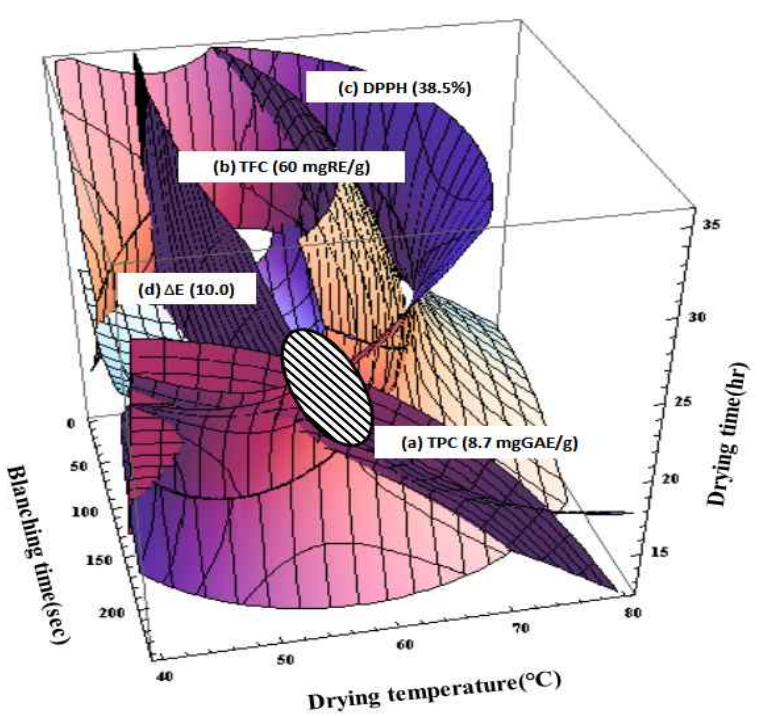

Fig. 7. Superimposed response surface of total polyphenol content, total flavonoid content, DPPH radical scavenging activity and color difference for optimal drying condition range of Cudrania tricuspidata extracts.

(a), TPC-8.7 mg GAE/g; (b), TFC-60 mg RE/g; (c), DPPH-38.5\%; (d), $\Delta \mathrm{E}-10.0$ as a function of blanching time, drying temperature and drying time.

Table 6. Comparison between predicted and experimental values for response variable of Cudrania tricuspidata at the given condition ${ }^{1)}$ within the range of optimal condition

\begin{tabular}{cccc}
\hline $\begin{array}{c}\text { Response } \\
\text { variables }\end{array}$ & $\begin{array}{c}\text { Predicted value } \\
(\mathrm{A})\end{array}$ & $\begin{array}{c}\text { Experimental value } \\
(\mathrm{B})\end{array}$ & $\mathrm{B} / \mathrm{A} \times 100(\%)$ \\
\hline $\mathrm{TPC}^{2)}(\mathrm{mg} \mathrm{GAE} / \mathrm{g})$ & 8.62 & 10.06 & 116.71 \\
$\mathrm{TFC}(\mathrm{mg} \mathrm{RE} / \mathrm{g})$ & 56.65 & 49 & 86.5 \\
$\mathrm{DPPH}(\%)$ & 40.26 & 44.99 & 111.75 \\
$\Delta \mathrm{E}$ & 11.69 & 10.53 & 90.08 \\
\hline
\end{tabular}

${ }^{1)} 240 \mathrm{sec}$ blanching time, $60^{\circ} \mathrm{C}$ drying temperature, and $24 \mathrm{~h}$ drying time. ${ }^{2)} \mathrm{TPC}$, total polyphenol content; TFC, total flavonoid content; DPPH, DPPH radical scavenging activity; $\Delta \mathrm{E}$, color difference. 
며 적합 모델식에 대입한 결과 $\mathrm{TPC}$ 는 $8.62 \mathrm{mg} \mathrm{GAE} / \mathrm{g}, \mathrm{TFC}$ 는 $56.65 \mathrm{mg} \mathrm{RE} / \mathrm{g}, \mathrm{DPPH}$ 는 $40.26 \%$ 그리고 $\Delta \mathrm{E}$ 는 11.69 로 나타났다. 예측 결과에 대해 모델식을 검증하기 위해 예측된 최적 범위 내 임의의 조건을 선정하였다. 블랜칭 처리 시간 240 초, 건조 온도 $60^{\circ} \mathrm{C}$, 건조 시간 24 시간의 조건 에서 확인실험을 진행하였고 확인실험 결과 TPC, TFC, $\mathrm{DPPH}, \Delta \mathrm{E}$ 는 각각 $10.06 \mathrm{mg} \mathrm{GAE} / \mathrm{g}, 49 \mathrm{mg} \mathrm{RE} / \mathrm{g}, 44.99 \%$, 10.53 으로 나타났다(Table 6). 적합 모델식에 대입한 예측값 과 비교하였을 때, 총 폴리페놀과 총 플라보노이드 함량이 다소 낮은 값을 나타냈지만 실험값은 예측값의 $86.5-116.71 \%$ 로 나타나 추출조건의 유효성이 인정되었다.

\section{요 약}

꾸지뽕 열매는 미생물에 의한 오염과 물러짐으로 저장기 간이 짧고 유통이 어렵다는 단점이 있다. 농산물에 적용할 수 있는 선도 유지 및 가공법은 여러 방법이 있지만 본 연구에서는 실질적으로 농민들이 적용할 수 있는 블랜칭 처리방법과 열풍 건조법에 대해 연구하였다. 먼저 블랜칭 처리 시간별로 꾸지뽕의 생균수를 측정하여 블랜칭 처리 시간이 증가할수록 미생물이 점차적으로 감소하는 것을 확인할 수 있었다. 그리고 블랜칭 처리 시간 및 건조 조건에 따른 건조 추세를 비교한 결과, $40^{\circ} \mathrm{C}$ 에서 건조 시 무처리구 보다 블랜칭 처리구가 더 빠른 수분 감소 효과를 나타내었 다. 하지만 건조 온도가 증가할수록 무처리구와 블랜칭 처 리구 간의 건조 추세 차이는 점점 줄어드는 것을 확인하였 다. 최종적으로 블랜칭 및 열풍건조의 최적 조건을 도출하 기 위해 반응표면 분석법을 이용하였다. 조건에 따른 total polyphenol content, total flavonoid content, DPPH radical scavenging activity, 색차 $(\Delta \mathrm{E})$ 의 예측값은 각각 $8.62 \mathrm{mg}$ $\mathrm{GAE} / \mathrm{g}, 56.65 \mathrm{mg} \mathrm{RE} / \mathrm{g}, 40.26 \%, 11.69$ 의 수치를 나타냈다. 최적 범위 내 임의의 조건 즉, $240 \mathrm{sec}$ 블랜칭 처리 시간, $60^{\circ} \mathrm{C}$ 건조 온도, $24 \mathrm{~h}$ 건조 시간에서 실험값은 $10.06 \mathrm{mg}$ $\mathrm{GAE} / \mathrm{g}, 49 \mathrm{mg} \mathrm{RE} / \mathrm{g} .44 .99 \%, 10.53$ 을 나타냈으며 예측값과 실험값은 유사한 값을 보였다.

\section{감사의 글}

본 연구는 전라북도동부권식품클러스터육성사업 중 순 창건강장수식품클러스터육성사업을 추진하고 있는 (재)순 창건강장수연구소의 연구과제의 일환으로 수행되었으며, 이에 감사를 드립니다.

\section{References}

1. Lee CB (1985) Dehanshikmuldogam (A field guide to
Korean plants). Hyangmoonsha, Seoul, Korea, p 285

2. Kangjoshinewhakwon : Jungyakdesajon (Great dictionary of Chinese medicine) (1985) $2^{\text {nd }}$ ed, Sohakkyan, Shanghai, China, p 2383

3. Park JH, Lee KW, Sung KS, Kim SS, Cho KD, Lee BH, Han CK (2012) Effect of diets with mulberry leaf and Cudrania tricuspidata leaf powder supplements on blood glucose-related biomarkers in streptozotocininduced diabetic rats. J Korean Soc Food Sci Nutr, 41, 766-773

4. Kang YK, Lee EA, Park HR (2012) Neuroprotective effect according to reactive oxygen species scavenging activity from extracts of Cudrania tricuspidata leaves. Korean J Food Cook Sci, 28, 821-828

5. Shin HS, Jeong HL, Hwang DB, Kim DU (2014) Cudrania tricuspidata root extract as whitening and antiwrinkle cosmetic agent. Korean Chem Eng Res, 52, 701-705

6. Jung GT, Ju IO, Choi SR, You DH, Noh JJ (2013) Food nutritional characteristics of fruit of Cudrania tricuspidata in its various maturation stages. Korean J Food Preserv, 20, 330-335

7. Lee HK, Kim YS (2015) Comparison of proximate composition of Curdrania tricuspidata Bureau fruit. J Agric Life Sci, 46, 22-26

8. Joo HY, Lim KT (2009) Protective effect of glycoprotein isolated from Cudrania tricuspidata on liver in $\mathrm{CCl}_{4}$-treated A/J mice. Korean J Food Sci Technol, 41, 93-99

9. Oh PS, Lee HJ, Lim KT (2009) Inhibitory effect of glycoprotein isolated from Cudrania tricuspidata Bureau on histamine release and COX-2 activity in RBL-2H3 cells. Korean J Food Sci Technol, 41, 405-412

10. Youn KS, Kim JW (2012) Antioxidant and angiotensin converting enzyme I inhibitory activities of extracts from mulberry (Cudrania tricuspidata) fruit subjected to different drying methods. J Korean Soc Food Sci Nutr, 41, 1388-1394

11. Seo MJ, Kang BW, Park JU, Kim MJ, Lee HH, Kim $\mathrm{NH}$, Kim KH, Rhu EJ, Jeong YK (2013) Effect of fermented Cudrania tricuspidata fruit extracts on the generation of the cytokines in mouse spleen cells. J Life Sci, 23, 682-688

12. Kang DH, Kim JW, Youn KS (2011) Antioxidant activities of extracts from femented mulberry (Cudrania tricuspodata) fruit, and inhibitory actions on elastase and tyrosinase. Korean J Food Preserv, 18, 236-243 
13. Choi SR, You DH, Kim JY, Park CB, Kim DH, Ryu J (2009) Antioxidant activity of methanol extracts from Curdrania tricuspidata Bureau according to harvesting parts and time. Korean J Medicinal Crop Sci, 17, 115-120

14. Kim HJ (2012) Antioxidant and antibacterial activity of extracts from Cudrania tricuspidata Bureau. MS Thesis, Chungnam National University, Korea, p 38-45

15. Kang JS, Cho HR, Han JS, Hur SH (2003) Hot water dipping treatment to improve storage quality of green red pepper. Korean J Food Preserv, 10, 261-266

16. Lee YJ, Lee HO, Kim JY, Kwon KH, Cha HS, Kim BS (2011) Quality characteristics of frozen Doraji (Platycodon grandiflorum) according to various blanching treatment conditions. Korean J Food Preserv, 18, 661-668

17. Lee MK, Kim SH, Ham SS, Lee SY, Chung CK, Kang IJ, Oh DH (2000) The effect of far infrared ray-vacuum drying on the quality changes of Pimpinella bracycarpa. J Korean Soc Food Sci Nutr, 29, 561-567

18. Mujurndar AS, Menon AS (1995) Drying of solids: principles, classification and selection of dryers. In: Handbook of Industrial Drying, Mujurndar AS (Editor), Marcel dekker, New York, NY, USA, p 1-39

19. Jung YK, Jang MY, Hwang IG, Yoo SM, Min SG, Jo YJ, Chun JY, Choi MJ (2015) Combination effect of various freezing and thawing techniques on quality and nutritional attributes of onions. J Korean Soc Food Sci Nutr, 44, 1492-1503

20. Chung HS, Seong JH, Lee YG, Kim HS, Lee JB, Youn KS (2009) Browning and moisture sorption characteristics of Rubus coreanus prepared by different drying methods. Korean J Food Preserv, 16, 797-803

21. Teng H, Lee WY (2015) Drying kinetics and optimization for thin-layer drying processes of raspberries (Rubus coreanus Miq.) using statistical models and response surface methodology. Korean J Food Preserv, 22, 1-11

22. Bhattarai S, Oh JH, Choi YS, Oh KC, Euh SH, Kim DH (2012) Microwave drying of sawdust for pellet production: kinetic study under batch mode. J Biosystems Eng, 37, 385-397

23. Singleton VL, Orthofer R, Lamuela-Raventos RM (1999) Analysis of total phenols and other oxidation substrates and antioxidants by means of Folin-Ciocalteu reagent. Methods Enzymol, 299, 152-178

24. Teng H, Ghafoor K, Choi YH (2009) Optimization of microwave-assisted extraction of active components from Chinese quince using response surface methodology. J Korean Soc Appl Biol Chem, 52, 694-701
25. Blois MS (1958) Antioxidant determination by the use of a stable free radical. Nature, 181, 1199-1200

26. Kim JW, Youn KS (2014) Phytochemical compounds and quality characteristics of Aster scaber Thunb. in response to blanching conditions and treatment with solutes. Korean J Food Preserv, 21, 694-701

27. Lim JH, Choi JH, Hong SI, Jeong MC, Kim DM (2005) Mild heat treatments for quality improvement of fresh-cut potatoes. Korean J Food Preserv, 12, 552-557

28. Chung SK, Shin JC, Choi JU (1992) The blanching effects on the drying rates and the color of hot red pepper. J Korean Soc Food Nutr, 21, 64-69

29. Pirone BN, De Michelis A, Salvatori DM (2014) Pretreatments effect in drying behaviour and colour of mature and immature 'Napolitana' sweet cherries. Food Bioprocess Technol, 7, 1640-1655

30. MAZZA G (1983) Dehydration of carrots: effects of pre-drying treatments on moisture transport and product quality. Int J Food Sci Technol, 18, 113-123

31. Borges SV, Mancini MC, Correa JLG, Leite JB (2011) Drying kinetics of bananas by natural convection: Influence of temperature, shape, blanching and cultivar. Sci agrotec, 35, 368-376

32. Demirel D, Turhan M (2003) Air-drying behavior of Dwarf Cavendish and Gros Michel banana slices. J Food Eng, 59, 1-11

33. Tomas-Barberan FA, Espin JC (2001) Phenolic compounds and related enzymes as determinants of quality of fruits and vegetables. J Sci Food Agric, 81, 853-876

34. Ghasemzadeh A, Ghasemzadeh N (2001) Flavonoids and phenolic acids: Role and biochemical activity in plants and human. J Med Plants Res, 5, 6697-6703

35. Hwang IG, Shin YJ, Lee S, Lee J, Yoo SM (2012) Effect of different cooking methods on the antioxidant properties of red pepper (Capsicum annuum L.). Prev Nutr Food Sci, 17, 286-292

36. Dewanto V, Wu X, Adom KK, Liu RH (2002) Thermal processing enhances the nutritional value of tomatoes by increasing total antioxidant activity. J Agric Food Chem, 50, 3010-3014

37. Jin CR, Cho CH, Nam TG, Cho YS, Kim DO (2015) Effects of hot air drying on the antioxidant capacity of Actinidia arguta $\times A$ deliciosa cv. Mansoo, a hardy kiwifruit. Korean J Food Sci Technol, 47, 539-543

38. Apak R, Guclu K, Demirata B, Ozyurek M, Esin CS, Bektasoglu B, Berker KI, Ozyur D (2007) Comparative 
evaluation of various total antioxidant capacity assays applied to phenolic compounds with the CUPRAC assay. Molecules, 12, 1496-1547

39. Martinez MV, Whitaker JR (1995) The biochemistry and control of enzymatic browning. Trends Food Sci Technol, $6,195-200$

40. Sulaiman A, Soo MJ, Farid M, Silva FVM (2015) Thermosonication for polyphenoloxidase inactivation in fruits: Modeling the ultrasound and thermal kinetics in pear, apple and strawberry purees at different temperatures. J Food Eng, 165, 133-140

41. Madamba PS (2002) The response surface methodology: an application to optimize dehydration operations of selected agricultural crops. LWT-Food Sci Technol, 35, 584-592 